\title{
Peran Psikolog dalam Bidang Pendidikan, Pemerintahan dan Industri
}

\author{
Muhamad Uyun \\ Fakultas Psikologi, Universitas Islam Negeri Raden Fatah Palembang, Indonesia \\ e-mail: muhamaduyun_uin@radenfatah.ac.id
}

\begin{abstract}
The purposes of this research were to find out the roles of psychologists in the scope of education, government and industry. The research used qualitative method and the data collection technique was interview. The key informants in all fields totaling 9 informants were selected by purposive sampling. The results of the study of the roles of psychologists in the field of education actualize the right action in the interaction between each educational factor especially on student acceptance, diversity of students, determining learning strategies and methods, conducting guidance and briefing as well as evaluating results. Furthermore, the roles of the psychologists in the field of government were to create a clean government, good integrity, professional and transparency. Lastly, the role of psychologists in industrial field were related to the development, maintenance and work productivity of employees as well as evaluating prospective employees.
\end{abstract}

Keywords: the roles of psychologist, education section, government section, industrial section

\begin{abstract}
Abstrak
Tujuan penelitian ini untuk mengetahui peran psikolog bidang pendidikan, pemerintahan dan industri. Penelitian menggunakan metode kualitatif dan teknik pengumpulan data menggunakan wawancara. Key informants semua bidang berjumlah 9 orang dipilih secara purposive sampling. Hasil penelitian menunjukkan peran psikolog bidang pendidikan mewujudkan tindakan yang tepat dalam interaksi antara setiap faktor pendidikan, terutama saat penerimaan peserta didik, diversity of student, menentukan strategi dan metode pembelajaran, melakukan bimbingan dan pengarahan serta evaluasi hasil. Selanjutnya peran psikolog bidang pemerintahan untuk menjadikan pemerintahan yang bersih, berintegritas, profesional dan transparan. Terakhir peran psikolog bidang industri berkaitan dengan pengembangan, pemeliharaan, dan produktivitas kerja karyawan serta mengevaluasi calon karyawan.
\end{abstract}

Kata Kunci: peran psikolog, bidang pendidikan, bidang pemerintahan, bidang industri

\section{Pendahuluan}

Pengukuran terhadap kepribadian merupakan suatu hak yang sangat penting karena kepribadian merupakan gambaran keseluruhan dari individu, dan pentingnya untuk memahami keseluruhan aspek yang berbeda dalam individu dan bagaimana hubungannya dengan orang lain. Selain itu, pengukuran kepribadian diperlukan untuk mempelajari individu yang kompleks, seperti keunikan seseorang, bagaimana interaksi dengan orang lain. Pada dasarnya setiap manusia pasti memiliki perbedaan, semua berbeda baik dalam hal kemampuan berpikir serta kemampuan dalam menjalankan aktivitasnya. Kajian menurut Calvin dan Lindzey (2005) menjelaskan terdapat tiga aspek psikologis yang dikaitkan dengan proses kehidupan psikis manusia, yaitu aspek emosional, aspek kognitif dan aspek hubungan interpersonal. Proses kehidupan manusia dikaitkan dengan apa yang dirasakan (emosional), dipikirkan (kognitif) dan yang diperbuat (hubungan interpersonal). Oleh karena itu proses tersebut harus dipahami dengan seksama.

Menurut Sobur (2010) setiap individu memiliki pemikiran dan tingkah laku yang akan ditampakkan dalam tingkah normal maupun tingkah abnormal. Dalam melakukan serangkaian tes psikologi dibutuhkan seorang psikolog yang sudah memiliki sertifikasi Psikolog di Indonesia yang 
tergabung dalam organisasi profesi bernama HIMPSI (Himpunan Psikologi Indonesia). Menurut HIMPSI dalam Kode Etik Psikologi Indonesia (2010), psikolog memiliki kewenangan untuk memberikan layanan psikologi yang meliputi bidangbidang praktik klinis dan konseling. Psikolog berwenang untuk menyelenggarakan konseling.

Indrawati (2015) menyebutkan bahwa psikolog menjalankan serangkaian tes sebagai langkah untuk mengumpulkan informasi secara objektif berkaitan dengan memahami karakter seseorang. Nur'aeni (2012) menjelaskan psikolog tidak hanya melakukan tes, melainkan mengklasifikasikan dan mendiagnosis berbagai gangguan psikis dan mendeskripsikan atau memahami secara intensif. Tingkah laku atau kepribadian individu merupakan sebuah produk dari aspek sosiobiopsikologis sehingga tes bertujuan untuk memperoleh deskripsi dari individu dan aspek-aspek tersebut. Selain itu hasil dari suatu tes akan digunakan sebagai prediksi untuk meramalkan atau mengidentifikasi perkembangan individu selanjutnya.

Nur'aeni (2012) mengklasifikasikan beberapa jenis tes psikis yang dapat digunakan sebagai evaluasi sesuai dengan kebutuhan dan tujuan dilakukannya penilaian tes. Misalkan pengukuran kinerja diperlukan tes untuk mengukur kecepatan, ketepatan dan ketahanan dalam produktivitas dan situasi kerja. Kemudian pengukuran akademik diperlukan tes untuk mengukur tingkat kecerdasan, bakat, kepribadian, dan minat. Sependapat dengan Marliani (2010) menjelaskan sebagai psikolog memilih suatu alat tes baik itu instrumen dan alat ukur lainnya sangat penting untuk mengkuantifikasikan hasil dari pengukuran. Instrumen ataupun alat ukur disesuaikan dengan perilaku aktual sebagai indeks yang valid untuk pengukuran psikologis seseorang seperti inteligensi, kreativitas, motivasi, prestasi, sikap, dan minat.

Dalam penelitian ini terfokus pada peran psikolog dalam bidang pendidikan, pemerintahan dan industri. Pertama peran psikolog dalam bidang pendidikan, berkaitan dengan serangkaian tes yang dilakukan dalam lingkungan pendidikan. Cristhoper (2018) menjelaskan peran psikolog dalam pendidikan berkaitan dengan kemampuan untuk menerapkan teori-teori psikologi serta untuk mengetahui karakteristik perserta didik. Watkins dkk. (2001) menyatakan psikolog tidak hanya melakukan penilaian terhadap hasil assessment saja melainkan juga memberikan pelayanan yang utuh terhadap beragam permasalahan dalam lingkup pendidikan, dan juga berperan penting untuk semua jenjang pendidikan. Dalam pendidikan erat kaitannya dengan proses belajar yang merupakan kegiatan inti interaksi antara peserta didik dan pendidik. Menurut Soemanto (2012) beberapa peran pokok psikolog dalam pendidikan meliputi: (1) hereditas, (2) pertumbuhan dan perkembangan, (3) proses-proses tingkah laku, (4) teori belajar, (5) pengukuran hasil belajar, (6) evaluasi hasil belajar, (7) transfer belajar, (8) kesehatan mental, (9) pendidikan watak, (10) hakikat dan ruang lingkup belajar.

Di Indonesia dalam UU No. 20 Tahun 2003 Tentang Sistem Pendidikan Nasional pada Pasal 3, berbunyi bahwa pendidikan Nasional berfungsi mengembangkan kemampuan dan membentuk karakter serta peradaban bangsa yang bermartabat dalam rangka mencerdaskan kehidupan bangsa. Hal ini bertujuan tidak hanya mencerdaskan peserta didik akan tetapi juga membentuk karakter anak menjadi lebih baik. Ruang lingkup peran psikolog dalam membentuk karakter dimulai dari penyusunan kurikulum yang sesuai dengan tahapan perkembangan usia peserta didik, buku pembelajaran yang cocok untuk membentuk IQ (intelligence quotient) dan EQ (emotional quotient) peserta didik sampai dengan kegiatan-kegiatan positif yang dapat dilakukan peserta didik, bahkan tenaga pengajar yang mampu bekerja secara efektif dan kreatif. Oleh karena itu 
psikolog dalam pendidikan memiliki peran yang sangat penting, adapun yang harus dilakukan adalah melakukan serangkaian tes. Selanjutnya hasil tes dapat digunakan untuk memeriksa inteligensi (IQ), kepribadian, prestasi akademik, minat dan bakat. Disamping itu, psikolog akan memeriksa hasil tes dan mengarahkan untuk penanganan lanjutan berdasarkan hasil tes.

Berdasarkan pernyataan Komisaris Komisi Perlindungan Anak Indonesia (KPAI) Listyarti, menjelaskan bahwa psikolog sangat penting untuk dilibatkan dalam lingkup pendidikan. Psikolog akan sangat membantu peserta didik maupun pendidik (guru) untuk saling berinteraksi dan berkomunikasi dengan baik dalam hal apapun yang berkaitan dengan permasalahan yang mengganggu kegiatan sekolah. Banyaknya kasus percobaan bunuh diri yang dilakukan siswa menjadi perhatian khusus bagi sektor pendidikan. Kasus bunuh diri mayoritas terjadi pada tingkat SMA atau SMK Negeri yang terakreditasi A, dimana dari 910 anak terdapat $5.3 \%$ cenderung ingin bunuh diri, 3\% sudah pernah melakukan percobaan bunuh diri. Hal ini menunjukkan bahwa potensi bunuh diri di kalangan anak sekolah cukup tinggi (Hafizhah, 2020).

Pada dasarnya permasalahan dalam bidang pendidikan membutuhkan seorang ahli dalam bidang kesehatan mental. Permasalahan lainnya dalam pendidikan yang sering terjadi adalah kesulitan siswa dalam mengikuti pembelajaran. Darimi (2016) menemukan banyak siswa yang mengalami kesulitan dalam mengikuti pembelajaran. Misalkan siswa terkesan lambat yang berhubungan dengan kegiatan belajar. Dari hasil pengamatannya menjelaskan terdapat dua faktor yang memengaruhi yaitu faktor internal (kecerdasan, bakat, minat, motivasi, kondisi dan keadaan fisik) dan faktor eksternal (lingkungan, ekonomi keluarga, sekolah dan masyarakat). Oleh karena itu adanya psikolog dalam pendidikan ini untuk mengantisipasi lebih dini suatu hal yang berkaitan dengan psikis dan mental siswa sehingga mencegah untuk tidak melakukan hal yang dapat berdampak negatif.

Kedua, peran psikolog dalam bidang pemerintahan. Hal ini dikaitkan dengan penggunaan psikologi sosial pemerintahan. Sebagai ilustrasi kaitannya teori psikologi sosial lebih menekankan pada mengamati dari sisi ekstern dan interaksi. Dari segi ekstern melibatkan lingkungan sosial, peristiwa atau kejadian, dan fisik. Sedangkan dari segi interaksi lebih menekankan pada kesehatan, emosi dan tingkat kesenangan seseorang. Peran psikolog dalam pemerintahan sebagai gambaran awal tentang psikis seseorang sebelum menjabat dalam bidang pemerintahan. Dalam Teori Garner dijelaskan bahwa psikologi sosial ditekankan dari psikis ideal dan moral sentimen. Hal tersebut yang akan menjadi tombak dalam kekuasaan, dimana harus dalam keselarasan dengan psikis konstitusi dari masyarakat. Pada dasarnya masing-masing individu memiliki perbedaan dari sudut pandang masyarakat, dimana psikis individual, kegeniusan dan keistimewaan masingmasing dalam kehidupan (Fahmi \& Ramdani, 2014). Dalam membangun politik yang baik seseorang maupun kelompok harus memiliki tingkat kesadaran yang tinggi. Sebagai contoh dalam pemilihan calon anggota dewan, dilakukan psikotes untuk melihat potensi mulai dari potensi kecerdasan (inteligensi umum) sampai dengan potensi minat dan bakat. Setelah dinyatakan masuk kandidat calon anggota, psikolog dihadirkan untuk memberikan stimulus sebagai langkah awal agar bisa beradaptasi dan mengetahui apa yang harus dilakukan serta berkembang setelah aktif bekerja (menjabat).

Dalam penelitian Putri dan Nihayah (2017) menjelaskan banyaknya perilaku menyimpang dalam bidang pemerintahan adalah korupsi. Tahun 2018 kasus korupsi banyak diberitakan, dimana mayoritas pelaku berasal dari anggota dewan, kejaksaan agung, mahkamah konstitusi, 
lembaga pemerintahan dan partai politik. Berdasarkan hasil temuannya menjelaskan terdapat faktor yang memengaruhi intensi anti korupsi seseorang yaitu integrasi, kognitif dan identitas moral individu. Diperkuat dengan hasil pengamatan lembaga psikologi menemukan seseorang yang melakukan tindak korupsi didasarkan karena adanya rasa kekuasan atau rasa ingin memiliki yang berlebihan. Sejalan dengan penelitian Winurini (2017) menjelaskan bahwa motivasi tertinggi seseorang melakukan korupsi adalah motif kekuasaan, berprestasi dan afiliasi. Oleh karena itu sangat dibutuhkan peran psikolog dalam jajaran pemerintahan. Hal ini yang menjadi perhatian khususnya peran psikolog sangat penting untuk membantu dalam mengevaluasi semua jajaran dalam bidang pemeritahan. Hal ini berpengaruh pada setiap tindak tanduk dan kegiatan anggota atau jajaran dalam pemerintahan yang nantinya sangat dipengaruhi oleh psikis individu.

Ketiga, peran psikolog dalam bidang industri, dimana konteks industri memainkan peran sangat penting. Salah satunya mengembangkan sumber daya manusia dan organisasi, terutama saat seleksi karyawan baru dengan melakukan serangkaian tes. Disamping itu peran psikolog memiliki banyak manfaat untuk mendapatkan sumber daya manusia yang berkompeten di bidangnya dan membentuk personal yang mampu bersaing serta menyesuaikan diri dengan kebutuhan tempatnya bekerja. Sebagai contoh perusahaan akan melakukan penyaringan tenaga kerja yang dibutuhkan maka, dilakukan psikotes untuk melihat potensi calon karyawan. Psikolog nantinya akan melakukan penilaian berkaitan dengan kondisi mental dan psikis untuk setiap calon karyawan. Disamping itu psikolog akan mengevaluasi karyawan lama berkaitan dengan kondisi mental saat ini. Hal ini sangat diperlukan untuk mengantisipasi karyawan jika mengalami beban mental lingkup kerja. Dengan adanya tes secara berkala bagi karyawan lama akan mampu meningkatkan produktivitas kerja, menciptakan manajemen keamanan kerja dan meningkatkan motivasi dan juga moral kerja karyawan. Selain itu dengan adanya lingkungan kerja dan sikap kerja yang baik akan menciptakan budaya kerja yang lebih sinergi dan memudahkan karyawan baru untuk beradaptasi dengan lingkungan kerja.

Gangguan psikis diramalkan oleh World Health Organization (WHO) hingga 2020 yang paling berbahaya nomor 2 setelah penyakit jantung adalah penyakit mental yang berkaitan erat dengan depresi. Kementerian tenaga kerja Jepang melakukan pengamatan terhadap 12.000 perusahaan. Hasil menunjukkan bahwa $65 \%$ pekerja mengeluhkan kelelahan fisik, $28 \%$ mengeluhkan kelelahan mental dan sekitar $7 \%$ pekerja mengeluh stres berat dan merasa tersisihkan. Terbukti bahwasanya faktor psikis yang banyak dirasakan oleh karyawan adalah kelelahan mental dan stres. Sama halnya di Indonesia dalam penelitian Rosita dan Hidayati (2014) menjelaskan pekerja perusahaan pada bagian produksi sebanyak $36.5 \%$ mengalami depresi dan $19.8 \%$ mengalami tingkat kecemasan. Oleh karena itu untuk mengantisipasi terjadi hal buruk yang dapat merugikan perusahaan diperlukan evaluasi karyawan berdasarkan pengamatan psikolog. Marliani (2015) menjelaskan keberadaan psikolog sangat dibutuhkan terutama pada saat penempatan dan promosi kerja, mutasi karyawan dan pada tahapan seleksi karyawan.

Secara keseluruhan psikolog akan mengevaluasi, menelaah dan menggambarkan hasil dan serangkaian tes yang dilakukan yang nantinya akan dapat dijadikan sebagai sumber informasi ataupun dalam pengambilan keputusan. Informasi yang diperoleh dari setiap individu dijadikan sebagai gambaran untuk peramalan performa seseorang. Psikolog yang akan melakukan tes harus memenuhi kualitas psikometri sehingga proses penilaian lebih akurat (Murphy, 2005). Peran psikolog digunakan dalam konteks 
pendidikan, pemerintahan dan industri, berperan sama dengan tujuan yang berbeda.

Berdasarkan uraian di atas dapat digambarkan bahwa psikolog memiliki banyak peran yang dominan dalam hal kemitraan, baik secara individu maupun kelompok, hal ini tidak lain adalah peran psikolog ataupun kelompok dengan kelompok dimana harus ada pemahaman yang sama untuk mencapai tujuan yang diinginkan. Pemahaman ini tidak dapat dicapai dengan instan, karena manusia memiliki perbedaan yang unik. Peran psikolog sebagai jembatan akan berusaha menemukan jalan yang terbaik melakukan assessment memadai dan hati-hati agar mendapatkan hasil semaksimal mungkin dan dapat dipertanggungjawabkan. Oleh karena itu artikel ini akan membahas lebih jauh peran psikolog dalam bidang pendidikan, pemerintahan dan industri.

\section{Metode Penelitian}

Jenis penelitian ini menggunakan pendekatan kualitatif. Tujuan penelitian ini adalah ingin mengungkap peran psikolog dalam bidang pendidikan, pemerintahan, dan industri. Pengungkapan tersebut melalui pengumpulan data tentang aspekaspek yang terkait sebagai upaya penempatan psikolog dalam berbagai bidang tersebut.

Objek dalam penelitian ini adalah mengenai peran psikolog dalam bidang pendidikan, pemerintahan, dan industri. Dalam penelitian ini sampel dipilih dengan menggunakan metode purposive sampling. Metode ini fokus kepada informan yang dipilih. Informan sebagai narasumber dilakukan secara langsung kepada key informan. Pemilihan key informan dilakukan secara random sampling, dimana sampel dipilih yang melibatkan psikolog dan secara sukarela dijadikan sampel. Hal ini mengingat tidak semua rekanan/ mitra lembaga psikologi bersedia dijadikan sampel, sehingga pemilihan sampel didasarkan pada pengelompokkan masing- masing bidang yaitu pendidikan, pemerintahan dan industri. Dalam penelitian ini key informants yaitu: 1) dalam bidang pendidikan, mengambil kepala sekolah dari masing-masing jenjang tingkat Sekolah Dasar (SD), Sekolah Menengah Pertama (SMP) dan Sekolah Menengah Atas (SMA); 2) dalam bidang pemerintahan, yakni calon anggota Bawaslu (Badan Pengawas Pemilu), anggota KPU (Komisi Pemilihan Umum), anggota dewan dan Karyawan BKD (Badan Kepegawaian Daerah) di wilayah Palembang; 3) dalam bidang industri, yakni perusahaan swasta murni dan perusahaan BUMN (Badan Usaha Milik Negara) dan BUMD (Badan Usaha Milik Daerah) di wilayah Palembang. Dalam penelitian ini diambil masing-masing 1 subjek yang sudah melibatkan peran psikolog di lembaganya khususnya di wilayah Palembang.

Pengumpulan data menggunakan teknik wawancara tak terstruktur. Selanjutnya, apabila peneliti sudah memperoleh gambaran persoalan-persoalan kemudian memilih tema-tema apa saja yang hendak peneliti dalami, maka peneliti akan menggunakan teknik wawancara semi terstruktur, yakni suatu wawancara yang menggunakan pedoman wawancara berisi tema-tema yang hendak digali sesuai materi penelitian. Hal yang perlu digarisbawahi bahwasanya dalam penelitian ini ingin menggali peran psikolog dalam 3 bidang, sehingga penelitian ini hanya fokus pada subjek yang secara langsung melibatkan psikolog untuk tujuan dan maksud masingmasing bidang.

Analisis data menggunakan teknik Miles dan Huberman (Miles dkk., 2014). Komponen-komponen analisis data model interaktif yaitu: 1) reduksi data (data reduction), pada tahap ini peneliti melakukan reduksi data dengan cara memilah, mengkategorikan dan membuat abstraksi dari catatan lapangan dan wawancara. 2) penyajian data (data display), peneliti membuat daftar awal kode 
yang sesuai dengan pedoman wawancara, kemudian untuk data yang sudah diberi kode dianalisis dalam bentuk refleksi dan disajikan dalam bentuk teks. 3) kesimpulan, penarikan atau verifikasi (conclusing drawing or verification). Dalam hal ini peneliti akan membuat kesimpulan dan argumentasi yang kuat dikaitkan dengan landasan teori sebagai acuan.

Uji keabsahan data menggunakan uji kredibilitas yang dilakukan dengan diskusi teman menggunakan bahan referensi berupa hasil rekaman wawancara dan triangulasi. Triangulasi dilakukan setelah pengambilan data dilakukan kepada informan lainnya seperti anggota masyarakat sekitar. Hal ini dilakukan untuk memperoleh ketepatan data dari hasil wawancara. Sistem triangulasi dilakukan secara jenuh sampai diyakini bahwa informasi yang diberikan pada saat wawancara dinilai benar. Kemudian selanjutnya dilakukan diskusi dengan teman atau rekan selama penelitian untuk ikut berpartisipasi dalam uji keabsahan.

\section{Hasil Penelitian dan Pembahasan}

\section{Peran Psikolog dalam Bidang Pendidikan}

Peran psikolog adalah suatu peran yang inhern dan disandang seseorang yang berfungsi sebagai konselor dan juga dikatakan sebagai apa yang diharapkan dari posisi yang dijalani. Perkembangaan saat ini semua tingkat pendidikan telah bekerja sama dengan beberapa lembaga-lembaga resmi dan profesional untuk mengadakan tes psikologi seperti inteligensi umum, kepribadian dan minat bakat. Menurut Lubis (2011) peran psikolog adalah untuk mencapai sasaran interpersonal dan intrapersonal, mengatasi defisit pribadi dan kesulitan perkembangan peserta didik, membuat keputusan dan rencana tindakan perubahan serta pertumbuhan, dan meningkatkan kesehatan serta kesejahteraan. Peran psikolog itu sendiri berperan dalam pen- didikan dari mulai tingkat pra sekolah, sekolah dasar, menengah pertama, menengah atas bahkan sampai perguruan tinggi yang mana memiliki tujuan sama dengan perbedaan cara penilaian.

Hasil evaluasi dari psikolog akan dijadikan acuan baik dalam penerimaan siswa dan mahasiswa baru, pemilihan program studi, mengetahui minat bakat ataupun kepribadian siswa dan mahasiswa. Secara keseluruhan dari hasil pengamatan bahwa setiap individu dapat diketahui gambaran kemampuan melalui adanya peran psikolog yang mengacu pada teoriteori Psikologi Kepribadian.

Berdasarkan hasil wawancara yang diperoleh dari narasumber berkaitan dengan peran psikolog dalam penilaian hasil tes:

"Psikolog disini memeriksa penilaian atau catatan dari hasil tes yang telah dilakukan berkaitan dengan tes minat bakat, kecerdasan dan kepribadian. Kalau interprestasi hasil kami serahkan semuanya kepada pihak yang lebih profesional, jadi kami hanya melihat hasilnya saja baru kami evaluasi bersama." (SD, 2 September 2019)

"Tes psikologi biasanya kami, bekerjasama dengan lembaga psikologi untuk melakukan tes kepada siswa kami pada saat masuk sekolah dan pada saat penentuan jurusan. Selain itu latihan-latihan untuk persiapan masuk Perguruan Tinggi atau yang mau bekerja, misalkan tes TPA, inteligensi umum dan kepribadian. Guru juga ikut berperan serta dalam evaluasi dari hasil tes yang telah dinilai oleh psikolognya untuk penentuan misalkan pemilihan jurusan atau penerimaan siswa." (SMA, September 2019) 
Berdasarkan ungkapan beberapa narasumber di atas dapat dikatakan lembaga pendidikan menggunakan peran psikolog dalam tes siswa atau mahasiswa, yang mana hasilnya nanti dijadikan bahan evaluasi bagi pemangku pendidikan sesuai dengan kebutuhan dari masing-masing tingkat pendidikan. Bagi tingkat menengah atas, tes psikologi dijadikan acuan dalam pemilihan jurusan yang tepat karena patokannya berdasarkan minat atau bakat dan kemampuan umum mata pelajaran tertentu. Sama halnya dengan penelitian Harackiewicz dkk. (2016) yang menjelaskan minat adalah proses motivasi kuat yang memberi energi pada pembelajaran, panduan akademik, dan lintasan karier, yang sangat penting untuk keberhasilan akademik. Penelitian Kahu dkk. (2017) menunjukkan minat dan tujuan individu siswa yang ada berinteraksi dengan pengajaran lingkungan untuk memicu minat situasional.

Perkembangan saat ini menunjukkan semua tingkat pendidikan telah bekerja sama dengan beberapa lembaga-lembaga resmi dan profesional untuk mengadakan tes seperti tes inteligensi umum, kepribadian dan minat bakat. Hasil tes yang diperoleh akan dijadikan acuan baik dalam penerimaan siswa atau mahasiswa baru, pemilihan program studi, mengetahui minat bakat ataupun kepribadian siswa atau mahasiswa.

Adapun kesimpulan dari peran psikolog dalam bidang pendidikan, sebagaimana disajikan pada tabel 1, berkaitan dengan tujuh hal. Pertama, penerimaan calon siswa/mahasiswa baru. Peran psikolog dapat membantu untuk menentukan kecerdasan (inteligensi umum), kepribadian dan kecocokan minat dan bakat untuk mahasiswa dalam memilih program studi. Hal ini sangat penting, dimana psikolog akan ikut mengevaluasi hasil tes untuk memberikan pilihan apakah siswa dan mahasiswa diterima atau ditolak. Dalam proses penerimaan calon siswa dan mahasiswa, biasanya psikolog melakukan serangkaian assesment.

Kedua, memahami pola kebiasaan, dimana kebiasaan seseorang dapat teridentifikasi melalui beberapa tes, sehingga dapat terlihat bagaimana reaksi saat menghadapi permasalahan tertentu. Setiap siswa masih akan menghadapi suatu permasalahan terutama dalam lingkup sekolah baik itu pertemanan atau pembelajaran. Adanya peran psikolog membantu dalam menangani hal tersebut dibantu dengan guru BK (bimbingan konseling) jika terdapat beberapa siswa yang mengalami permasalahan akademiknya.

Ketiga, identifikasi kemampuan dan potensi. Hal ini sifatnya objektif akan tetapi bisa dijadikan acuan atau gambaran ke depannya. Selain itu dapat mengukur siswa berkaitan dengan minat dan bakat masingmasing siswa. Hal ini berkaitan dengan pemilihan jurusan pada siswa SMA, pemilihan program studi untuk calon mahasiswa, yang dapat ditentukan melalui tes minat dan bakat.

Keempat, memahami perbedaan siswa (diversity of student), setiap individu memiliki karakter yang berbeda-beda, dengan demikian guru atau pendidik harus mampu memahami adanya berbagai karakter tersebut baik dari cara berpikir, kemampuan, minat dan bakat yang dimiliki masing-masing. Evaluasi hasil tes dari psikolog akan membantu guru/ pendidik untuk dapat menciptakan pembelajaran yang efektif dan efisien, penentuan jurusan, penilaian kepribadian dan pemilihan studi untuk mahasiswa.

Kelima, menentukan strategi dan metode dalam pembelajaran. Penentuan strategi dalam pembelajaran maupun metode dalam pembelajaran harus menyesuaikan dengan perkembangan peserta didik. Misalnya bagi peserta didik berkebutuhan khusus maka metode dalam pembelajaran disesuaikan dengan kondisi kebutuhan. Oleh karena itu yang menjadi pembeda jika siswa memiliki kebutuhan 
khusus atau penanganan lebih khusus dibandingkan peserta didiknya maka baru diberikan penanganan pembelajaran yang berbeda di sekolah khusus. Peran psikolog dalam hasil tes akan menjelaskan tentang karakter belajar siswa sehingga strategi dan model pendidikan sudah dapat menyesuaikan dengan kondisi siswa. Hal ini supaya proses kegiatan pembelajaran bisa berjalan dengan maksimal.

Keenam, sebagai input untuk melakukan bimbingan dan pengarahan. Di sekolah, guru atau pendidik tidak hanya sebagai pengajar melainkan menjadi pembimbing bagi siswanya terutama berkaitan dengan permasalahan di dalam lingkup akademik. Oleh karena seorang pendidik perlu memahami pendekatan emosional yang nanti bisa diarahkan oleh psikolog, sehingga akan terbentuk hubungan yang mampu menjaga kondisi selama proses pembelajaran.

Ketujuh, sebagai evaluasi hasil dari pembelajaran. Dari hasil tes yang telah dilakukan psikolog akan memberikan hasil interpretasi dari penilaian masing-masing siswa kepada guru atau pendidik. Dengan demikian, hasil tes yang diperoleh dapat dijadikan evaluasi untuk melihat kemampuan peserta didik tanpa membedabedakan.

Tabel 1

Peran Psikolog dalam Bidang Pendidikan

\begin{tabular}{cl}
\hline No & \multicolumn{1}{c}{ Peran Psikolog } \\
\hline 1 & $\begin{array}{l}\text { Proses penerimaan calon siswa atau } \\
\text { mahasiswa baru }\end{array}$ \\
2 & $\begin{array}{l}\text { Identifikasi pola kebiasaan menghadapi } \\
\text { permasalahan }\end{array}$ \\
3 & $\begin{array}{l}\text { Identifikasi kemampuan dan potensi, minat } \\
\text { dan bakat } \\
\text { Memahami perbedaan siswa (diversity of } \\
\text { student) } \\
\text { Menentukan strategi dan metode } \\
\text { pembelajaran } \\
\text { Pengambilan keputusan dalam melakukan } \\
\text { bimbingan dan pengarahan } \\
\text { Evaluasi hasil dari proses interpretasi hasil } \\
\text { tes untuk tenaga pendidik }\end{array}$ \\
\hline
\end{tabular}

Kondisi ini sebagai evaluasi guru untuk menilai jika ada peserta didik yang mengalami permasalahan berkaitan dengan kegiatan pembelajaran. Sehingga guru dapat mengetahui tindakan apa yang seharusnya dilakukan.

Berdasarkan uraian di atas berkaitan dengan peran psikologi yang disimpulkan pada tabel 1. Hasil tersebut sesuai dengan pendapat Dalyono (2001) bahwa dalam dunia pendidikan, peran psikolog sebagai: 1) seleksi penerimaan siswa baru, 2) pelayanan dan bimbingan penyuluhan untuk siswa, 3) penyusunan kurikulum dan perencanaan pendidikan, 4) interaksi kegiatan pembelajaran, 5) sebagai evaluasi sekolah, dan 6) penentuan metode pembelajaran. Dalam penelitian Nezhad dan Vahedi (2011) psikolog memiliki peran untuk ikut dalam menentukan konsep pembelajaran yang tepat, yang mana setiap anak memiliki kemampuan dan hak untuk belajar bagaimanapun kondisinya.

Selain itu psikolog akan mengarahkan atau memberikan informasi dari setiap hasil tes kepada guru berkaitan dengan perkembangan peserta didik, karena pada dasarnya masing-masing memiliki kemampuan mental dan cara belajar yang berbeda-beda. Tujuan dasarnya untuk membantu siswa maupun mahasiswa untuk memiliki gambaran kepribadian, minat serta bakatnya untuk dapat dioptimalkan selama menjalani proses pendidikan.

Sejalan dengan ungkapan Daulay (2014), hasil tes psikologis dapat digunakan untuk mendiagnosis, monitoring dan sebagai evaluasi. Adapun tes yang dilakukan psikolog secara umum yaitu tes bakat dan minat, inteligensi umum dan tes kepribadian. Hasil dari penilaian tes tersebut dimanfaatkan sebagai seleksi sebelum masuk sekolah, penentuan penjurusan, program bimbingan karier untuk siswa SMK, dan penanganan pada kasus yang terjadi dalam lingkup pendidikan. Misalnya beberapa yang perlu penanganan seperti siswa yang mengalami kesulitan belajar, kesulitan dalam 
penyesuian diri, dan sulit untuk berkosentrasi. Dengan adanya psikolog dapat membantu dalam pemecahan permasalahan untuk tindakan lebih lanjut.

Menurut Saam (2010) dalam pidato pengukuhannya sebagai guru besar bidang Psikologi Pendidikan, mengartikan seseorang akan belajar lebih baik jika sesuai dengan minat dan bakatnya serta kemampuan yang dimiliki. Penjurusan di waktu SMA pada hakikatnya mempertimbangkan 3 aspek yaitu minat, bakat dan kemampuan, akan tetapi pada kenyataannya banyak yang terpengaruh karena adanya ajakan teman atau ikutikutan. Bahkan ada orang tua yang menghendaki anaknya untuk memilih jurusan tertentu akan tetapi tidak didukung oleh prestasi akademik dan minat anak yang bersangkutan. Saam juga melakukan penelitian pada tahun 1994 pada pidatonya yang menyimpulkan bahwa prestasi akademik yang diperoleh pada pelajaran tertentu tidak mendukung minat memilih jurusan yang diinginkan. Misalnya dalam kasus yang ditemui, dimana prestasi siswa yang paling menonjol adalah pelajaran ilmu sosial (IPS), akan tetapi berminat pada kelompok IPA (ilmu alam). Hal ini terbukti pada jenjang pendidikan tinggi, dimana hasil pengamatan pada penerimaan calon mahasiswa di Universitas Riau pada hasil Seleksi Nasional Penerimaan Mahasiswa Baru (SNPMB) siswa yang memilih jurusan IPS banyak yang berasal dari jurusan IPA sewaktu SMA. Alasannya karena setelah masuk IPA merasa tidak berkompetensi sehingga memilih jurusan pada kelompok IPS. Dalam penelitian Harackiewicz dan Hulleman (2010) menjelaskan tentang minat menjadi point dalam pencapaian prestasi akademik. Oleh karena itu, kebimbangan atas pemilihan jurusan dapat teratasi jika dilakukan pemeriksaan secara klinis berkaitan dengan potensi yang dimiliki.

Woods dan Burns (2018) menjelaskan peran psikolog dalam lingkup sekolah yaitu menyajikan permasalahan dalam suatu penilaian sehingga terinterventarisasi ke dalam informasi yang lengkap, mengungkapkan serangkaian strategi untuk mendukung peserta didik, wali peserta didik dan guru. Berdasarkan hasil serangkaian uji yang dilakukan psikolog diketahui potensi dan dilihat pula prestasi trial melalui prestasi akademik yang diperoleh di sekolah maka dapat diprediksi jurusan yang cocok untuk masing-masing siswa.

Dengan demikian peran psikolog dalam dunia pendidikan sangat penting. Psikolog dalam lingkup pendidikan seharusnya dapat dijadikan kebutuhan utama untuk membantu memajukan sektor pendidikan yang baik dalam bidang akademik maupun pengembangan kurikulum dan operasional pendidikan. Hal ini diperlukan untuk dapat memprediksi apa yang dibutuhkan peserta didik, apa yang harus diberikan peserta didik dan bagaimana penanganan yang tepat untuk dapat menciptakan peserta didik yang memiliki karakter pendidikan kuat.

\section{Peran Psikolog dalam Bidang Pemerintahan}

Dalam bidang pemerintahan, peran psikolog sangat penting. Biasanya dikaitkan dengan teori psikologi sosial dan politik (lebih menekankan kepada perilaku politik). Teori Psikologi Sosial berkaitan dengan tingkah laku dalam konteks sosial. Kajian ini menegaskan individu dipengaruhi oleh lingkungan sosial. Oleh karena itu Psikologi Sosial memberikan intervensi untuk membentuk tingkah laku supaya lebih adaptif dan berguna dalam lingkungan sosialnya. Sedangkan perilaku politik dikaitkan dengan cara pengambilan keputusan dalam politik itu sendiri. Oleh karena itu perilaku politik itu sendiri dikaitkan dengan perilaku sosial yang memiliki kepentingan dalam suatu masyarakat atau golongan masyarakat itu sendiri (Mulkhan, 2009).

Dalam bidang pemerintahan peran psikolog untuk melakukan pengukuran 
perilaku seseorang dimana akan dilakukan serangkaian tes sesuai dengan kebutuhan individu atau sektor pemerintahan. Hal ini bertujuan untuk dapat mengetahui sikap dan perilaku secara psikologis setiap anggota dalam jajaran pemerintahan, sehingga dapat terdeteksi lebih dini jika terdapat penyimpangan-penyimpangan perilaku. Perilaku individu dalam hal ini berkaitan dengan warga sipil. Mengutip hasil penelitian Rindermann dkk. (2011), ilmu-ilmu sosial secara tradisional mengasumsikan bahwa pendidikan adalah penentu utama perilaku dan orientasi politik warga. Beberapa penelitian juga menunjukkan bahwa inteligensi memiliki pengaruh. Menurut sebuah teori yang konseptualisasi inteligensi sebagai fenomena penduduk kota (kelas menengah, sipil) harus mempromosikan sikap sipil, kebiasaan dan norma-norma seperti ketekunan, ketertiban serta kebebasan, sehingga menumbuhkan perkembangan kognitif orientasi politik. Biasanya individu dengan kecerdasan yang lebih, cenderung ke arah orientasi politik yang kurang ekstrem. Hasil ini dibahas dalam konteks negara yang berbeda dan dalam konteks model teoretis yang berbeda tentang hubungan antara sikap politik dan IQ, dimana keduanya memiliki hubungan yang sangat rendah.

Berdasarkan ungkapan narasumber berkaitan dengan peran psikolog, sebagai berikut:

"Psikolog dalam lingkup kami, sangat berperan penting bahkan kami bekerja sama dengan beberapa lembaga psikolog ketika melakukan rekruitmen calon anggota KPU. Tanpa peran serta psikolog, kami tidak akan mampu melihat atau menilai perilaku seseorang, karena pada dasarnya kami mencari orang yang tidak hanya memiliki IP atau nilai akademik yang bagus melainkan faktor psikologisnya harus sesuai. Menginggat tanggung jawab sebagai anggota KPU dituntut untuk transparan, bersih dan jujur dalam segala hal." (KP, 10 September 2019)

"Seorang Psikolog sangat penting perannya dalam membantu kami dalam melakukan tes ketika pemilihan anggota BAWASLU. Peran mereka sangat dibutuhkan untuk mengukur tingkat kecerdasan, tingkah laku, kejiwaan setiap anggota. Kami sebagai anggota Bawaslu dituntut untuk memiliki etos kerja yang tinggi sifat jujur dan bersih menjadi pedoman kami sebagai anggota BAWASLU. Oleh karena itu tes psikologi menjadi syarat utama dalam pemilihan anggota. Dimana integritas serta konsistensi personal seseorang untuk melihat tanggapan individu ketika menghadapi beban kerja" (BW, 12 September 2019)

Berdasarkan ungkapan narasumber di atas dapat dikatakan bahwa peran psikolog dalam bidang pemerintahan menjadi pedoman yang sangat penting dalam pengukuran karakter calon anggota. Setiap organisasi memiliki pedoman masingmasing untuk menerima individu menjadi anggota. Sebagai anggota dewan pengabdi masyarakat, perilaku dan tingkah laku setiap anggotanya harus sangat diperhatikan karena menyangkut kejujuran, keterbukaan (transparansi) tanpa bertindak yang akan merugikan satuan organisasi. Sehingga ke depannya diperoleh anggota yang benar-benar bersih, berintegritas dan profesional serta transparan sampai batas masa jabatan selesai. Adapun yang menjadi penilaian adalah integritas, kecerdasan, kepribadian, ketahanan kerja dan kepimpinan. Kepribadian dan kompetensi 
para calon anggota dengan dasar bahwa perilaku politik, termasuk kepemimpinan, dipengaruhi oleh faktor kepribadian dan lingkungan tempat mereka berada serta memprediksi perilaku politik jika terpilih.

Penjelasan Pervin dkk. (2012) dalam penelitiannya berpendapat jenis karier yang dipilih seseorang berhubungan erat dengan sikap kepribadian. Seseorang dipastikan akan memilih jenis karier sesuai dengan karakteristiknya, dibandingkan dengan pekerjaan lainnya yang tidak sesuai. Biasanya jika pekerjaan tidak sesuai maka individu tersebut tidak akan bertahan lama. Hal ini yang menjadi pertimbangan bahwa dengan melihat kepribadian individu membantu organisasi dalam pengambilan keputusan. Selain kepribadian hal umum yang harus diperhatikan adalah inteligensi (kecerdasan).

Penelitian Hamm dkk. (2019) menjelaskan dalam bidang pemerintahan terdapat istilah kepercayaan politik, dimana hal tersebut sebagai fondasi dalam pemerintahan. Seseorang yang tidak memiliki kepercayaan dalam politik tidak akan memiliki dukungan penuh oleh masyarakat. Selain kepribadian, kepercayaan juga memiliki peran yang sama, dalam hal ini berkaitan dengan ilmu organisasi yang membuat argumen spesifik mengenai sifat psikologis dan mekanisme konstruk. Fahmi dkk. (2019) menjelaskan nilai karakter psikologis yang menjadi pertimbangan penting dalam orientasi politik adalah nilai moral. Hal ini disebabkan psikologis politik sangat erat kaitannya dengan ideologi politik seseorang yang menjadi fondasi dasar untuk berperilaku politik. Sektor pemerintahan saat ini juga melibatkan psikolog di dalamnya dengan menjalin kerjasama lembaga psikologi. Seseorang yang akan menjabat pada jajaran pemerintahan, sebelumnya pasti melakukan serangkaian tes psikologi untuk pendeteksi-an fisik maupun psikis. Biasanya hal tersebut dilakukan oleh seorang psikolog dengan melakukan serangkaian tes assesment.
Tabel 2

Peran Psikolog dalam Bidang Pemerintahan

\begin{tabular}{ll}
\hline No & \multicolumn{1}{c}{ Peran Psikolog } \\
\hline 1 & $\begin{array}{l}\text { Menggambarkan perilaku maupun reaksi } \\
\text { dalam kondisi lingkungan baru ataupun } \\
\text { berlawanan dengan konsentrasi mengenai } \\
\text { gejala sosial tertentu }\end{array}$ \\
2 & $\begin{array}{l}\text { Indentifikasi sifat dasar, lebih menekankan } \\
\text { kepada aspek tingkah laku anggota dewan }\end{array}$ \\
3 & $\begin{array}{l}\text { Menganalisis psikis individu (ideal psikis } \\
\text { serta moral sentimen) terkait keselarasan } \\
\text { dengan psikis konstitusi }\end{array}$ \\
4 & $\begin{array}{l}\text { Pedoman untuk penilaian hasil assesment } \\
\text { calon anggota dewan }\end{array}$ \\
\hline
\end{tabular}

Adapun bidang pemerintahan yang membutuhkan peran psikolog seperti pemilihan calon anggota dewan, KPU, Bawaslu, dan CPNS (Calon Pegawai Negeri Sipil). Peran psikolog dalam hal ini untuk mengetahui karakter, perilaku, kepribadian atau kejiwaan, bakat, keterampilan dan kemampuan yang dimiliki. Sehingga ke depannya diperoleh aparatur negara yang benar-benar bersih, memiliki integritas dan profesional serta transparan sampai batas masa jabatan selesai. Adapun yang menjadi penilaian adalah integritas, kecerdasaan, kepribadian, ketahanan kerja dan kepemimpinan. Kepribadian dan kompetensi para calon anggota dengan dasar bahwa perilaku politik, termasuk kepemimpinan, dipengaruhi oleh faktor kepribadian dan lingkungan tempat mereka berada serta memprediksi perilaku politik jika terpilih.

Adapun peran psikolog dalam pemerintahan itu sendiri sebagaimana disajikan pada tabel 2. Pertama, menggambarkan perilaku maupun reaksi baik individu maupun kelompok. Gambaran perilaku untuk melihat bagaimana sikap seseorang terhadap lingkungan baru dan gejala sosial yang ditimbulkan. Hal ini cenderung lebih mengarah kepada pendeteksian rasa simpati dan empati calon anggota dewan. Dalam bidang pemerintahan, gambaran perilaku dan reaksi sangat penting berkaitan dengan sikap pengabdian terhadap masyarakat. Seseorang yang memiliki reaksi tidak stabil 
akan sangat menggangu pola pikir sehingga akan menimbulan reaksi negatif. Oleh karena itu sebagai calon anggota dewan dalam lembaga pemerintahan, pengontrolan terhadap reaksi apapun sangat penting untuk dimiliki.

Kedua, menggambarkan sifat dasar individu. Hal ini berkaitan dengan mempelajari tingkah laku masyarakat umum yang akan mencalonkan diri dalam lembaga pemerintahan. Peran yang digambarkan lebih mengarah kepada pendeteksian minat dan bakat. Minat diartikan sebagai rasa suka individu terhadap sesuatu, sedangkan bakat lebih menekankan kepada keinginan yang mendasar, kecerdasan dan pembawaan yang dibawa sejak lahir. Dalam bidang pemerintahan minat dan bakat menjadi faktor penting sebagai calon anggota dewan ataupun jabatan politik lainnya. Seseorang yang tidak memiliki bakat di bidang pemerintahan atau politik akan mengalami kesulitan dalam menjalankan tugas dan pekerjaannya, sama halnya dengan minat dimana keinginan untuk terjun dalam bidang pemerintahan atau politik sangat memengaruhi tingkat pencapaian ke depannya. Oleh karena itu selain inteligensi umum, setiap calon anggota dewan dalam bidang pemerintahan harus diketahui seberapa besar minatnya terhadap bidang ini, dengan dilakukannya tes minat dan bakat. Pada dasarnya tes minat dan bakat yang dihasilkan sebagai gambaran awal dari psikologis seseorang sehingga dapat digunakan sebagai acuan dalam penilaian.

Ketiga, menganalisis psikis individu. Dalam teori Garner menekankan kepada ideal psikis serta moral sentimen. Keduanya sebagai tombak dalam kekuasaan, yang mana harus ada keselarasan dengan psikis konstitusi. Seseorang memiliki kegeniusan dan keistimewaan terhadap kehidupan, kaitannya setiap anggota mempunyai kesadaran yang tinggi untuk membangun politik yang baik, dimana sebagian anggota dewan berasal dari masyarakat. Dalam bidang pemerintahan, psikis menjadi faktor bahwa calon anggota dewan tersebut layak dipercaya oleh masyarakat, dimana memiliki moral kejiwaan yang baik. Hal tersebut menjadi syarat utama sebagai wakil rakyat yang lolos menjadi anggota karena ke depannya memegang peran yang besar untuk membuat sistem pemerintahan menjadi lebih baik dari sebelumnya.

Keempat, menganalisa hasil dan evaluasi tes, dimana hasil evaluasi sebagai patokan untuk penilaian hasil assesment calon anggota dewan. Peran psikolog tidak hanya menganalisa melainkan melakukan seperangkat tes sesuai dengan tes yang dibutuhkan karena masing-masing tes memiliki kegunaan dan fungsi yang sesuai. Hal ini sangat membantu dalam bidang pemerintahan sejauhmana calon anggota dewan layak untuk diterima atau tidak dari hasil tes. Pada dasarnya hasil tes yang didapat sifatnya tidak tetap, akan tetapi dapat dijadikan evaluasi berkaitan dengan kondisi psikologis seseorang yang terdeteksi saat ini dan prediksi untuk jangka panjang.

Tingkat pencapaian dalam pemerintahan untuk menjadikan pemerintahan yang bersih, memiliki integritas yang baik, profesional dan memiliki transparansi dibutuhkan orang-orang yang berkomitmen tinggi dan memiliki perilaku yang baik. Adanya peran psikolog dalam melakukan tes menjadi pedoman dasar untuk terpilihnya anggota legislatif setelah menjalankan serangkaian tes. Peran psikolog menjadi pondasi utama dari hasil tes psikologi yang telah dilakukan untuk dapat memberikan hasil interpretasi dan mengevaluasi dengan beberapa pihak terkait (tim pelaksana pemilihan calon anggota dewan).

Berdasarkan hasil tersebut sebagai penentu calon anggota lolos pada tahap selanjutnya (layak) atau sebaliknya. Pada dasarnya psikolog akan memberikan gambaran, penjelasan dan pemahaman dari hasil evaluasi tentang perilaku dan harapan untuk dapat memilih calon anggota dewan 
dengan perilaku dan tingkah laku yang berpegang teguh terhadap tuntutan sosial dalam masyarakat untuk menjadikan pemerintah yang demokratis.

\section{Peran Psikolog dalam Bidang Industri}

Dalam dunia industri setiap orang yang berperan di dalamnya dituntut untuk mampu berkerja dengan efektif. Industri dikatakan berhasil jika dapat bersaing dengan pesaingnya. Oleh karena itu sumber daya manusia (SDM) sebagai salah satu aset yang harus dikelola dengan baik. Hal ini berkaitan dengan bagaimana memperoleh sumber daya manusia (SDM) yang memiliki integritas tinggi terhadap perusahaan atau industri. Tujuan dari rekrutmen adalah mendapatkan SDM (calon karyawan) yang memungkinkan pihak manajemen untuk memilih atau menyeleksi calon sesuai dengan kualifikasi yang dibutuhkan. Dalam proses ini sangat erat kaitannya dengan peran psikolog, dimana hasil evaluasi akan sangat menentukan perilaku, karakter, bahkan kepribadian seseorang sebelum diterima menjadi karyawan, karena hal ini berkaitan secara langsung terhadap produktivitas kerja ke depannya. Psikolog dalam industri berperan sebagai mediator dalam proses produktivitas kerja, pemeliharaan karyawan dan penanganan permasalahan dalam lingkup industri. Disamping itu penting dalam meningkatkan produktivitas kerja yang berkaitan dengan penerimaan karyawan. Dalam lingkup industri proses perencanaan, dan pengorganisasian serta pengarahan SDM menjadi hal yang sangat komplek.

Menurut Waluyo (2013) ilmu psikologi dapat dikembangkan dan diaplikasikan dengan berbagai teori umum serta pendekatan untuk mendeteksi perilaku dan mental individu. Hasil riset menjelaskan bahwa psikolog dalam bidang industri memiliki peran penting, dimana sebanyak $50 \%$ penilaian manager HRD (Human Resources Department) mengatakan "Iya". Adapun peran psikolog dalam industri seperti pengembangan manajemen sumber daya manusia seperti perekrutan, seleksi dan penempatan, motivasi kerja, serta pelatihan dan pengembangan. Pada dasarnya setiap karyawan yang mengalami permasalahan dalam perilaku berdampak besar pada kinerja perusahaan. Kondisi ini sangat wajar mengingat semua penggerak dalam perusahaan mengandalkan sumber daya manusia seutuhnya yang mana saling berinteraksi satu dengan lainnya. Susanti (2012) menjelaskan bahwa untuk menentukan jenis pekerjaan sangat dipengaruhi oleh kepribadian seseorang yang mana bila dikaitkan dengan teori Myers Bringgs Type Indicator (MBTI) kepribadian adalah pola pikir, perasaan dan tingkah laku yang merupakan karakter yang membedakan satu dengan yang lainnya.

Cable dan O'Driscoll (2010) menjelaskan seorang psikolog pada tingkat analisis tinggi dalam bidang pekerjaan tertentu (posisi jabatan tinggi), akan sedikit lebih berbeda dengan psikolog pada bidang lainnya. Hal ini mungkin saja karena adanya cerminan dari kebutuhan posisi kerja, sehingga membutuhkan peran yang lebih mendalam untuk menghasilkan SDM yang unggul. Peran psikolog pada dasarnya menerapkan prinsip-prinsip keilmuan psikologi, yang mencakup seluruh lingkup industri. Oleh karena itu seorang psikolog harus memiliki kemampuan yang berbeda dengan psikolog lainnya, dengan memperluas ruang, terus mengembangkan diri, terus mencoba-coba ilmu psikolog yang baik digunakan dalam era saat ini, dan beberapa hal lainnya yang dianggap sebagai peluang untuk aplikasi lebih lanjut dari ilmu perilaku. Sama halnya dengan penjelasan Augustyn dan Cllie (2008) bahwa asumsi tentang pengetahuan para psikolog bidang industri menyarankan untuk memperluas ilmu dan praktisinya. Secara tidak langsung akuisisi pengetahuan dan mengusulkan pandangan post-modern antara teori dan praktik, dimana akan diakhiri dengan saran untuk merevitalisasi antara teori dan praktik. 
Berikut ungkapan narasumber berkaitan dengan peran psikolog dalam bidang industri serta prosedur peran psikolog dalam perekrutan, adalah sebagai berikut:

"Excatly, perannya sangat penting untuk membantu kami melakukan serangkaian tes kepribadian. Walaupun di perusahaan kami ada yang lulusan psikologi untuk bagian HRD, akan tetapi untuk tes seleksi kami tetap bekerjasama dengan lembaga psikologi yang lebih berkompeten. Prosedur psikolog dalam melakukan rekruitmen biasanya menyiapkan serangkain tes untuk mengukur kemampuan calon karyawan, banyak sekali tes yang harus dilakukan oleh calon karyawan. Dari hasil tes yang telah dilakukan, psikolog akan mengevaluasi dan menginterprestasikan hasil dari masing-masing tes dan akan disimpulkan lolos atau tidaknya. Jika lolos maka lanjut tahap selanjutnya biasanya adalah wawancara" (PS2, 25 September 2019)

"Peran psikolog yang jelas penting pak, alasannya ya karena sangat dibutuhkan terutama dalam proses rekruitmen karyawan untuk melakukan tes. Karena kami tidak mampu atau berkompetensi dalam hal tes, sehingga melibatkan orang ketiga yang ahli dalam melakukan tes psikologi. Tessesuai dengan standar pada umumnya yaitu tes inteligensi, kepribadian, kecerdasan dan ketahan kerja. Psikolog biasanya akan melakukan serangkaian tes yang akan dilewati oleh para calon karyawan, biasanya 1 hari kami bisa melakukan tes dibagi menjadi 3 sesi tergantung jumlah pelamar" (BU, 26 September 2019)

"Serangkaian tes psikologi yang dilakukan ya pak, pada dasarnya sih sama mungkin dengan lainnya seperti kepribadian, inteligensi umum dan ketahanan kondisi kerja. Psikolog akan melakukan beberapa tes kepada pelamar, kemudian dari hasil tes baru akan diketahui hasilnya apakah pelamar lolos tes psikologi atau tidaknya. Disamping itu biasanya kami melakukan konsultasi untuk tentang perkembangan lanjutan karyawan, untuk melihat secara berkala kepribadian setiap karyawan bagaimana mengalami gangguan kejiwaan seperti stres, tekanan ataupun lainnya" (BD, 28 September 2019)

Berdasarkan ungkapan narasumber di atas bahwa perusahaan dan industri baik itu swasta maupun negeri memanfaatkan peran psikolog dalam meningkatkan produktivitas kerja yang berkaitan dengan penerimaan karyawan, sifat karyawan dan lain sebagainya. Beberapa faktor penting dalam karakteristik pekerja yang sukses secara psikologis, yaitu percaya diri, berorientasi tinggi, berani mengambil risiko dan berorientasi terhadap orang lain. Pada dasarnya karyawan yang berkompeten merupakan aset terpenting untuk kunci keberhasilan organisasi atau perusahaan. Oleh karena itu pemilihan karyawan sangat ditentukan dari proses rekrutmen.

Peran psikolog dalam pengembangan sumber daya manusia dalam lingkup perusahaan sangat berguna untuk perkembangan perusahaan dalam jangka panjang, sehingga menjaga dan mengevaluasi secara berkala itu sangat penting. Adapun peran psikolog dalam bidang industri sebagaimana disajikan pada tabel 3 berdasarkan pada empat hal.

Pertama, proses rekrutmen dan seleksi calon karyawan. Banyak polemik yang dihadapi pada proses rekrutmen seperti pemenuhan posisi yang harus sesuai kebutuhan perusahaan, jenis pekerjaan yang sangat komplek sehingga harus benarbenar memilih calon karyawan yang tepat. Disamping itu dalam proses rekrutmen 
membutuhkan sebuah standar yang berkaitan dengan psikologis calon karyawan seperti intelegensi, kemampuan, minat dan bakat, ketahanan kerja yang sesuai apabila sudah lolos dari proses seleksi. Oleh karena itu peran psikolog sebagai ahli psikologi merupakan salah satu kunci dalam keberhasilan rekrutmen ini, ditentukan dari metode yang dipakai seperti tes inteligensi umum, tes prestasi, tes kemampuan spesifik, pengetahuan pekerjaan dan keterampilan. Dalam penelitian Irawan (2014) dijelaskan bahwa permasalahan dalam proses rekrutmen, penempatan karyawan, akan jauh lebih kompleks mengingat masing-masing individu berbeda. Oleh karena itu yang harus dilakukan adalah cermat dalam memilih dan mempertimbangkan dalam pemilihan calon karyawan.

Kedua, menggambarkan perilaku calon karyawan ataupun karyawan. Berkaitan dengan bagaimana tingkah laku khususnya dalam lingkup kerja. Dalam hal ini peran psikolog sangat penting untuk mengenali, mendiagnosis dan juga menjelaskan kejadian atau perilaku dan berbagai tata krama yang terjadi dalam kondisi tertentu di sebuah perusahaan. Pada dasarnya perilaku seseorang sangat memengaruhi performance kerjanya, jika seseorang memiliki perilaku yang menyimpang maka performance kerja tidak akan tercapai. Menganalisis perilaku sumber daya manusia baik itu calon karyawan maupun karyawan tetap tetap harus dilakukan secara berkala.

Ketiga, diferensiasi dan integritas tinggi dari setiap karyawan, dimana keyakinan karyawan terhadap perusahaan memegang peranan penting. Dalam hal ini harus mampu membedakan antara aktivitas yang harus dilakukan serta dibutuhkan, hal ini dikaitkan dengan integritas calon karyawan terhadap perusahaan.

Keempat, evaluasi pengembangan, pemeliharaan, dan produktivitas kerja. Pengembangan berkaitan dengan perubahan dalam area kerja seperti perubahan tuntutan kerja, prosedur pemerintah, struktur dalam organisasi serta perkembangan teknologi. Pemeliharaan berkaitan dengan penghubung, dimana psikolog berperan sebagai penghubung seperti melakukan bimbingan konseling bagi karyawan khususnya yang mengalami permasalahan berkaitan dengan sikap, kepribadian, tingkah laku untuk menjembatani hubungan industri dengan sesama karyawan, antar kolega atau pengusaha lainnya dan dengan pemerintahan. Berkaitan dengan produktivitas kerja, dimana psikolog melakukan pelatihan dan pengembangan, meningkatkan motivasi dan juga moral kerja karyawan, menciptakan teknik pengawasan kinerja, menentukan sikap kerja yang baik sehingga bisa mengajarkan karyawan mengenai cara mudah beradaptasi dengan lingkungan kerja baru. Penentuan calon karyawan dari hasil rekrutmen masing-masing industri berbeda-beda tergantung dari posisi jabatan yang dibutuhkan.

Peran psikolog berhubungan dengan pekerjaan dan organisasi. Dalam suatu organisasi memiliki elemen yang sangat kompleks, salah satunya adalah SDM, dimana SDM memegang kendali akan pelaksanaan produktivitas industri. Oleh karena itu dibutuhkan kecermatan dalam pengambilan keputusan menentukan SDM pada saat rekrutmen. Dalam hal ini peran psikolog memegang peranan untuk dapat mengevaluasi dan mendeteksi berkaitan dengan kepribadian dari setiap calon karyawan.

Tabel 3

Peran Psikolog dalam Bidang Industri

\begin{tabular}{|c|c|}
\hline No & Peran Psikolog \\
\hline 1 & Rekrutmen dan seleksi calon karyawan. \\
\hline 2 & $\begin{array}{l}\text { Identifikasi dan mendiagnosis perilaku } \\
\text { calon karyawan ataupun karyawan dalam } \\
\text { lingkup kerja. }\end{array}$ \\
\hline 3 & $\begin{array}{l}\text { Diferensiasi dan integritas tinggi dari } \\
\text { setiap karyawan }\end{array}$ \\
\hline 4 & $\begin{array}{l}\text { Evaluasi pengembangan, pemeliharaan, } \\
\text { dan produktivitas kerja }\end{array}$ \\
\hline
\end{tabular}


Pada dasarnya pengelolaan organisasi adalah proses pengelolaan manusia, karena semua organisasi yang bertujuan harus berorientasi dengan dan melalui manusia. Di dalam sebuah industri pasti akan terjadi interaksi sosial. Perusahaan membutuhkan adanya mana-jemen sumber daya manusia untuk membantu terwujudnya tujuan perusahaan.

Peran psikolog dalam ketiga bidang memiliki kesimpulan yang sama yaitu mengevaluasi, mendeskripsikan dan memberikan hasil yang berkaitan dengan kesehatan mental dan psikis seseorang. Adapun yang membedakan adalah cara tes dan cara penilaian untuk masing-masing tes yang dibutuhkan. Pada dasarnya psikolog memiliki peran yang setiap saat dibutuhkan. Setiap individu pasti memiliki permasalahan baik itu mahasiswa atau siswa, karyawan maupun jajaran pemerintahan dengan faktor penyebab yang berbeda-beda baik dari segi internal maupun eksternal. Dalam hal tersebut diperlukan peran psikolog untuk mengatasi masalah yang memengaruhi kondisi mental dan kesehatannya.

\section{Simpulan}

Berdasarkan hasil analisis berkaitan dengan peran psikolog dalam bidang pendidikan, pemerintahan, dan industri, diperoleh simpulan bahwa peran psikolog bidang pendidikan untuk membantu dalam penindakan psikologis yang tepat dalam lingkungan pendidikan. Hal ini berkaitan dengan seluruh kegiatan dalam lingkup pendidikan baik untuk peserta didik, pendidik (guru) maupun manajemen pendidikan yang dilibatkan. Adapun perannya adalah: 1) proses penerimaan calon siswa/ mahasiswa baru, 2) memahami pola kebiasaan berkaitan dengan perilaku, 3) mengidentifikasi kemampuan dan potensi, 4) memahami dan menggambarkan perbedaan siswa (diversity of student), 5) menentukan strategi dan metode pembelajaran, 6) sebagai input untuk melakukan bimbingan dan pengarahan, dan 7) sebagai evaluasi hasil dari pembelajaran.

Peran psikolog dalam bidang pemerintahan memiliki peran yang sangat penting untuk menjadikan pemerintahan yang bersih, integritas yang baik, profesionalitas dan memiliki transparansi dibutuhkan orang-orang yang berkomitmen tinggi dan memiliki perilaku yang baik. Peran psikolog dalam pemerintahan itu sendiri yakni: 1) menggambarkan perilaku maupun reaksi baik individu, 2) menggambarkan sifat dasar seseorang dalam hal politik dengan kata lain dalam pemerintahan mempelajari aspek tingkah laku anggota masyarakat umum, 3) menganalisis psikis individu, dan 4) menganalisa hasil dan evaluasi tes.

Peran psikolog dalam bidang industri sangat penting dimana semua aspek individual berhubungan dengan pekerjaan dan organisasi terutama adalah SDM memegang kendali akan pelaksanaan produktivitas industri. Adapun peran psikolog dalam industri berdasarkan hasil wawancara dengan beberapa narasumber dapat disimpulkan yakni: 1) proses rekrutmen dan seleksi calon karyawan, 2) menggambarkan perilaku calon karyawan ataupun karyawan, 3) diferensiasi dan integritas tinggi dari setiap karyawan, dan 4) evaluasi pengembangan, pemeliharaan, dan produktivitas kerja.

\section{Daftar Pustaka}

Aamodt, M. G. (2004). Applied industrial organizational psychology, 4th Wardsworth-Thomson.

Augustyn, J. C., \& Cillié, G. G. (2008). Theory and practice in Industrial Psychology: Quo vadis. SA Journal of Industrial Psychology, 34(1), 70-75. https://doi.org/10.4102/sajip.v34i1.419

Cable, D. A. J., \& O'Driscoll, M. P. (2010). The practice of industrial organisational psychology in New Zealand. New Zealand Journal of Psychology, 39(3). 
Christoper, G. (2018). Peranan psikologi dalam proses pembelajaran siswa di sekolah. Jurnal Warta, (58).

Cottam, M. L., Dietz-Uhler, B., Mastors, E., \& Preston, T. (2010). Introduction to political psychology. Psychology Press.

Darimi, I. (2016). Diagnosis kesulitan belajar siswa dalam pembelajaran aktif di sekolah. Jurnal Edukasi, 2(1), http://doi.org/10.22373/je.v2i1.689

Daulay, N. (2014). Implementasi tes psikologi dalam bidang pendidikan. Jurnal Tarbiyah, 21(2), 1-20. http://doi.org/10.30829/tar.v21i2.13

Dalyono. (2001). Psikologi pendidikan. Rineka Cipta.

Fahmi, I., Takwin, B., \& Muhamad, R. (2019). Nilai moral sebagai prediktor orientasi politik pada anggota organisasi keagamaan. Psympathic: Jurnal Ilmiah Psikologi, 6(2). https://doi.org/10.15575/psy.v6i2.6260

Fahmi, I., \& Ramdani, Z. (2014). Profil kekuatan karakter dan kebajikan pada mahasiswa berprestasi. Psympathic: Jurnal Ilmiah Psikologi, 1(1), 98-108. https://doi.org/10.15575/psy.v1i1.471

Hall, C. S., \& Lindzey, G. (2005). Introduction to theories of personality. John Wiley And Sons Inc.

Harackiewicz, J. M., \& Hulleman, C. S. (2010). The importance of interest: The role of achievement goals and task values in promoting the development of interest. Social and Personality Psychology Compass, 4(1). 42-52. https://doi.org/10.1111/j.17519004.2009.00207.x

Harackiewicz, J. M., Smith, J. L., \& Priniski, S. J. (2016). Interest matters: The importance of promoting interest in education. Policy Insights Behav Brain Sci, 3(2), 220-227. https://doi.org/10.1177\%2F237273221 6655542

Irawan, A. (2014). Pentingnya aspek psikologi industri dalam pengembangan sumber daya manusia
(Studi literatur). Program Studi Manajemen, Fakultas Ekonomi Universitas Jenderal Achmad Yani. Proceedings SNEB 2014.

Indrawati, S. W. (2012). Assesmen psikologis. [online]. File Departemen Psikologi Pendidikan dan Bimbingan FIP UPI. Tidak diterbitkan. [17 Mei 2020]

Kahu, E., Nelson, K., \& Picton, C. (2017). Student interest as a key driver of engagement for first year students. Student Success, 8(2), 55-66.

Lubis, N. L. (2011). Memahami dasardasar konseling dalam teori dan praktek. Kencana Prenada Media Grup.

Marliani, R. (2010). Pengukuran dalam penelitian psikologi. Psympathic: Jurnal Ilmiah Psikologi, 3(1). 107-120. https://doi.org/10.15575/psy.v3i1.2180

Marliani, R. (2015). Psikologi industri dan organisasi. Pustaka. Setia.

Miles, M. B., Huberman, A. M., \& Saldana, J. (2014). Qualitative data analysis, a methods sourcebook, Edition 3. Terjemahan Tjetjep Rohindi Rohidi. Sage Publications.

Moleong, L. J. (2014). Metodologi penelitian kualitatif. PT Remaja Rosda Karya.

Mulkhan, A. M. (2009). Politik santri. Kanisius Almond.

Murphy, S. (2005). The sport psychology handbook: A complete guide to today's best mental training techniques. Human Kinetics.

Nezhad, A. S., \& Vahedi, M. (2011). The role of educational psychology in teacher education programs. WCPCG 2011. Procedia - Social and Behavioral Sciences, 30(2011), 327$330 . \quad$ https://doi.org/ 10.1016/j.sbspro.2011.10.064

Nur'aeni. (2012). Tes psikologi: Tes inteligensi dan tes bakat. Universitas Muhammadiyah Purwokerto Press.

Pervin, L. A., Cervone, D., \& Oliver, P. J. (2012). Psikologi kepribadian: Teori 
dan penelitian, Edisi ke-9. Kencana Prenada Media Group.

Putri, D. A., \& Nihayah, Z. (2017). The effect of moral integrity, lifestyle and organizational culture on anticorruption intention. TAZKIYA Journal of Psychology 22(2). http://doi.org/10.15408/tazkiya.v22i2.8 413

Rindermann, H., Mendoza, C. F., \& Woodley, M. A. (2011). Political orientations, intelegence and education. Journal ERIC. ELSEVIER, 40(2), 217-225. http://doi.org/10.1016/j.intell.2011.11. 005

Rosita, L. D., \& Hidayati, E. (2014). Penyakit psikologis yang sering dialami pada buruh pabrik di PT. Ungaran Indah Busana. Jurnal Keperawatan Komunitas, 2(2), 70-75.

Saam, Z. (2010). Psikologi konseling. Rajawali Pres.

Sobur, A. (2010). Psikologi umum dalam lintasan sejarah. CV. Pustaka Setia.

Susanti, N. (2012). Aplikasi psikologi berbasis web untuk menentukan jenis pekerjaan sesuai dengan kepribadian seseorang menggunakan teori MyersBriggs Type Indicator. Thesis. Majalah Ilmiah INFORMATIKA, 3(2).
Sarwono, S. W. (2009). Pengantar umum psikologi. PT. Bulan Bintang.

Soemanto, W. (2012). Psikologi Pendidikan. Rineka Cipta.

Sugiyono. (2013). Metode penelitian kuantitatif kualitatif dan $R \& D$. Alfabeta.

Watkins, M. W., Crosby, E. G., \& Pearson, J. L. (2001). Role of the school psychologist (Perceptions of school staff). School Psychology International SAGE Publications (London, Thousand Oaks, CA and New Delhi), 22(1), 6473.

Waluyo, M. (2013). Psikologi industri. Akademia Permata.

Woods, M. C., \& Burns, J. R. (2018). School camp refusal and reluctance: The role of the school psychologist. Journal of Psychologists and Counsellors in Schools, 28(2), 235247.

Winurini, S. (2017). Perilaku korupsi di Indonesia dalam perspektif teori motivasi. Majalah Info Singkat Kesejahteraan Sosial, IX(03). 